\title{
Concurrent skin and nerve histology in leprosy and its role in the classification of leprosy
}

\author{
SURRINDER KAUR, VINOD K. SHARMA, \\ PRASANTA BASAK, INDERJEET KAUR \& \\ BISHAN D. RADOTRA \\ Departments of Dermatology, Venereology and Leprology and \\ Pathology, Postgraduate Institute of Medical Education and \\ Research, Chandigarh, India
}

\section{Accepted for publication 20 November 1992}

Summary Concurrent skin and nerve histology was evaluated in 60 leprosy patients (25 BT, $28 \mathrm{BL}$ and $7 \mathrm{LL}$ ). The twin aims were to study the comparative histology and the usefulness of nerve histology in the classification of the disease. In BT patients, clinical and histological classification was in agreement in 11 $(44 \%)$ skin and $17(68 \%)$ nerve biopsies. Concurrent skin and nerve histology was in consonance in $14(56 \%)$ BT patients, while in $6(24 \%)$ patients, only nerve histology was helpful in the classification of the disease, the skin histology being non-specific. Nerve histology was classified as BL in $3(12 \%)$ BT patients, the skin histology was non-specific.

In the BL group, the histology of $23(82.4 \%)$ nerve biopsies correlated with the clinical classification, in contrast to skin histology which correlated with clinical assessment in $19(68 \%)$ patients only. In the LL patients, the histology of nerve correlated with the clinical classification in 5 patients (71.4\%), compared to histology of the skin in $4(57 \%)$ patients only. The GF was higher in the nerves than in the skin throughout the leprosy spectrum (BT, BL, LL); the difference was, however, marginal in BL leprosy. The average bacteriological index (BI) was higher in nerves $(4+)$ compared to that of skin histology and slit skin smears $(3+)$ in BL leprosy. There was, however, no difference in the BI of the slit skin smears, skin and nerve biopsies in lepromatous leprosy.

It is inferred that the neural histology is of ten more useful than skin histology in the classification of leprosy patients $(p<0.01)$ and it correlates better with clinical classification, particularly in the borderline tuberculoid disease. The neural histology gave a better idea about the bacterial load in the BT, BL patients. It is proposed that bacteriologically negative patients clinically and histologically classified as BT, but with nerve histology more consistent with BL, should be considered multibacillary for purposes of therapy.

Address correspondence to: Dr S. Kaur, Professor and Head, Department of Dermatology, Venereology and Leprology, Postgraduate Institute of Medical Education and Research, Chandigarh 160012 , India. 


\section{Introduction}

Although the main parameters for the diagnosis and classification of leprosy are related to the skin, leprosy is primarily a disease of the peripheral nerves. The clinical diagnosis of leprosy is largely based on characteristic skin lesions in association with thickened nerves and the presence of anaesthesia. Demonstration of acid fast bacilli (AFB) in slit skin smears (SSS), and histopathology of the skin are commonly used to confirm the diagnosis and classification of the disease. The histopathology of the skin lesions usually provides adequate information about the type of leprosy. The role of neural histology in diagnosis and classification of leprosy has been recently highlighted. ${ }^{1}$ In the majority of the cases the lesions in the nerves were found to be more bacillated than the skin, and persisted af ter the skin lesions had regressed. ${ }^{2-4}$

The present study was undertaken to compare the histopathology of skin and nerves in the biopsies taken simultaneously, its correlation with the clinical classification, and to ascertain the usefulness of neural histology in the classification and selection of a therapeutic regimen.

Classification of leprosy is not only important for a better understanding of the disease but also for treatment purposes. The concept of multibacillary leprosy was established with an idea of formulating its therapeutic strategy.

This paper mostly highlights the role of neural pathology in the treatment policy of leprosy in general and borderline tuberculoid leprosy in particular. There are two distinct clinical subsets of BT leprosy, one group is close to TT (TTs - BT) with few skin lesions and few thickened nerves and much intact CMI and SSS - ve, while the other group is close to $\mathrm{BB}(\mathrm{BB}-\mathrm{BT})$, with multiple lesions $(\geqslant 10)$, multiple thickened nerves, much compromised CMI and SSS + ve. Using WHO-1988 guidelines, there is no difficulty in treating the patients of BT who are SSS + ve from skin, but the real problem is selecting the treatment for BT patients who are SSS - ve. Though they are SSS - ve and histopathology of the skin shows nonspecific changes and no AFBs, many of them frequently show specific granuloma and AFBs in their nerves. According to WHO guidelines, we are probably undertreating these BT patients, who may be a potential source of resistance and relapse. In view of their SSS negativity there is no other monitoring guideline to measure the adequacy of $W H O-P B R$ in these subsets of BT leprosy. Therefore, histopathology of nerves is certainly an important tool in monitoring the treatment of this group of patients.

\section{Materials and methods}

We selected 60 consecutive untreated patients with leprosy from the leprosy clinic held at the Postgraduate Institute of Medical Education and Research, Chandigarh, India. We used the Ridley-Jopling classification of leprosy. ${ }^{8}$ A lepromin test was done in all 60 patients, using Dharmendra antigen. ${ }^{9}$ All the patients were subjected to parallel skin and nerve biopsies. Full thickness skin biopsies were taken from infiltrated plaques, fixed in Zenker's formalin and stained with haematoxylin \& eosin and Fite-Faraco stain for lepra bacilli. The biopsies were studied for the location and type of cells composing the granuloma, the presence or absence of subepidermal free zone, the destruction of nerves and appendages, and the presence of AFBs. The histology was classified into the 5 
conventional groups, TT, BT, BB, BL and LL. The granuloma fraction (GF), which is the fraction of the dermis occupied by granuloma in a section observed under low power objective expressed decimally, was also determined. ${ }^{10}$

Nerve biopsies were performed from thickened, purely sensory nerves, such as radial cutaneous $(n=51)$, sural $(n=2)$ greater auricular $(n=2)$, or other cutaneous nerves in the proximity of skin lesions $(n=3)$. Ulnar nerve biopsy $(n=2)$ was obtained during open drainage of nerve abscesses. Fixation and staining of the nerve biopsy specimens was undertaken in the same way as for skin biopsies. Apart from the cellular morphology, the GF was determined by estimating the fraction of nerve tissue occupied by granuloma. We used the histopathological criteria laid down by Ridley for the nerve biopsy classification of leprosy. "'

The data was analysed using Chi-square to study the role of neural histology in leprosy classification and its correlation with the clinical classification.

\section{Results}

The 60 patients studied included $25 \mathrm{BT}$ and $35 \mathrm{BL} / \mathrm{LL}$ patients (28 BL, $7 \mathrm{LL}$ ). All BT patients were slit smear negative. The BL patients had a mean bacteriological index (BI) of $3+$ and lepromatous patients had BI of $4+$ and above. All BL/LL patients were lepromin negative. The demographic details of the patients are shown in Table 1.

\section{BORDERLINE TUBERCULOID LEPROSY}

In the clinically BT patients there were 25 skin biopsies; 11 were classified as BT, 3 as TT; the skin histology could not be classified in the remaining 7 biopsies as they showed only nonspecific features. Of the 25 nerve biopsies studied, 17 showed features of BT, 3 were TT, 3 had BL histology and 2 showed nonspecific neuritis. The difference between the skin and nerve histology classification was highly significant $(p<0 \cdot 01)$.

\section{Clinico-histological Correlation}

In the BT patients, the neural histology correlated with clinical classification in $17(68 \%)$ patients, compared to skin histology which was consistent in $11(44 \%)$ patients only. The

Table 1. Demographic details of 60 patients

\begin{tabular}{lll}
\hline & \multicolumn{2}{c}{ Type of leprosy } \\
\cline { 2 - 3 } Characteristic & \multicolumn{1}{c}{ BT } & \multicolumn{1}{c}{ BL/LL } \\
\hline Number of patients & 25 & 35 \\
Mean age in years (range) & $26(16-42)$ & $36(16-62)$ \\
Sex & $20 \mathrm{M}, 5 \mathrm{~F}$ & $29 \mathrm{M}, 6 \mathrm{~F}$ \\
Mean duration in months (range) & $8(6-24)$ & $24(6-48)$ \\
Number of patches (range) & $3 \cdot 6(1-10)$ & Innumerable \\
Lepromin & All + ve & All negative \\
Bacteriologic indices (BI/MI) & $(2+$ to 3+) & \\
& No AFB & $3 \cdot 2+(3+$ to $4+)$ \\
\hline
\end{tabular}


Table 2. Neural histology in BT leprosy

\begin{tabular}{lccccc}
\hline & & \multicolumn{3}{c}{$\begin{array}{c}\text { Number } \\
\text { classified }\end{array}$} & \\
\cline { 3 - 5 } Tissue & $\begin{array}{c}\text { No. of } \\
\text { patients studied }\end{array}$ & BT & TT & BL & $\begin{array}{c}\text { Number not } \\
\text { classified }\end{array}$ \\
\hline Skin & 25 & 11 & 3 & 0 & 11 \\
Nerve & 25 & 17 & 3 & 3 & 2 \\
\hline
\end{tabular}

Neural $v s$ skin histology $=p<0 \cdot 02$.

Classified $v$ s not classified $=p<0.01$.

neural histology was helpful in the classification of the disease spectrum in $23(92 \%)$ patients, whereas dermal histology was only significant in $14(56 \%)$ patients (Table 2, $p<0.02$ ). The difference became even more significant if $2 \mathrm{BT}$ patients who were not confirmed by skin or nerve biopsy are excluded from the analysis $(p<0 \cdot 01)$.

The analysis of parallel skin and nerve histology in the BT group showed concordance in 14 patients (11 BT, 3 TT). In all, 6 nerve biopsies were classified as BT and 3 as BL; however, the skin histology showed nonspecific features in these patients.

The mean granuloma fraction (GF) was higher in the nerves $(0 \cdot 38)$ than in the skin biopsies classified as BT (0-19). Lymphocytes and epithelioid cells were more abundant in nerves compared to skin. Caseation was present in 8 nerve biopsies. AFBs were demonstrated in 8 nerve biopsies whereas no acid-fast bacilli were demonstrated in slit skin smears and skin biopsies.

\section{BORDERLINE LEPROMATOUS AND LEPROMATOUS LEPROSY}

Of the 28 clinically BL patients, the skin biopsy was classified as BL in 19, BB in 2 and in the remaining 7 the histology was nonspecific. Of the 28 nerve biopsies in this group, 23 were classified as $\mathrm{BL}$, one as $\mathrm{BB}$ and in 4 neuritis was nonspecific. The mean granuloma fraction was 0.5 in nerve biopsies compared to 0.4 in skin biopsies. The average BI in skin biopsies was similar to skin slit smear results $(3+)$. However, the BI in the nerve biopsies was higher, with a mean of $4+$. There was no statistically significant difference in the skin and nerve histology as regards the correlation with clinical classification in BL and LL patients (Tables 3 and 4). The skin and nerve histology showed almost similar features.

Table 3. Neural histology in BL leprosy

\begin{tabular}{lccccc}
\hline & & \multicolumn{3}{c}{$\begin{array}{c}\text { Number } \\
\text { classified }\end{array}$} \\
\cline { 3 - 5 } $\begin{array}{l}\text { Tissue } \\
\text { studied }\end{array}$ & $\begin{array}{c}\text { Number of } \\
\text { patients studied }\end{array}$ & BL & LL & BB & $\begin{array}{c}\text { No. not } \\
\text { classified }\end{array}$ \\
\hline Skin & 28 & 19 & 0 & 2 & 7 \\
Nerve & 28 & 23 & 0 & 1 & 4 \\
\hline
\end{tabular}

Skin $v s$ neural histology $=p>0.05$.

Classified $v s$ not classified $=p>0.05$. 
Table 4. Neural histology in lepromatous leprosy

\begin{tabular}{lccccc}
\hline & & \multicolumn{3}{c}{$\begin{array}{c}\text { Number } \\
\text { classified }\end{array}$} & \\
\cline { 3 - 5 } $\begin{array}{l}\text { Tissue } \\
\text { studied }\end{array}$ & $\begin{array}{c}\text { Number of } \\
\text { patients studied }\end{array}$ & LL & BL & BB & $\begin{array}{c}\text { Number not } \\
\text { classified }\end{array}$ \\
\hline Skin & 7 & 4 & 2 & 0 & 1 \\
Nerve & 7 & 5 & 2 & 0 & 0 \\
\hline
\end{tabular}

Neural $v s$ skin histology $=p>0 \cdot 05$.

Classified $v s$ not classified $=p>0.05$.

The granuloma fraction was, however, higher in the nerves $(0 \cdot 7)$ than in the skin biopsies $(0 \cdot 5)$. All specimens of nerve and skin biopsies were positive for AFB, and there was no difference in the mean BI at either site.

\section{Discussion}

Though the Ridley-Jopling classification is widely accepted, its histological component refers only to skin with the presumption that there may be no significant difference in the classification in the skin and neural histology. However, discrepancies have lately been brought out showing that many nerve biopsies show histological grading lower than the skin. ${ }^{1,2}$

The value of the study of neural histology in the diagnosis of doubtful cases of leprosy was documented by Nilsen et al. ${ }^{1}$ who found it to be diagnostic of leprosy in one-third of patients when skin histology showed nonspecific features. The significance of neural histology in the classification of leprosy is less well documented. Mukherjee \& Mishra ${ }^{13}$ found neural histology to be more useful in the classification of leprosy in one-third of patients, in whom skin had indeterminate or nonspecific features. The skin and nerve histology was found to be qualitatively similar when granuloma was well developed at both sites. Similarly in the present study, neural histology was found to be significantly better in classifying leprosy, especially in the borderline tuberculoid group, as nonspecific changes were less frequent in the nerves $(p<0.01$; Table 2$)$. The difference was, however, not significant in the BL-LL spectrum. Ridley \& Ridley, ${ }^{12}$ in a study of concurrent skin and nerve histology in 42 patients, found similar features for purposes of classification in the polar forms of leprosy (TT, LL). We observed similar histological findings in skin and nerves in lepromatous leprosy. We did not have clinically diagnosed TT patients. However, 3 patients with TT histology in skin showed similar features in the nerves.

Caseation in the histopathological sections of nerves is well documented in TT and BT leprosy. Ridley ${ }^{11}$ considered it to be more indicative of subpolar tuberculoid leprosy (TTs). Foci of caseation necrosis were large in some of the nerves we studied, the nerves were irregularly thickened and nodular, and the findings were considered to be suggestive of nerve abscess. Caseation was not seen in the corresponding skin biopsies, indicating that delayed hypersensitivity to Mycobacterium leprae antigen was better manifest in nerves in these patients. 
The relevance of lower immunological grading and heavy bacterial load in the nerves is debated. ${ }^{1,14}$ Nerves are protected sites for $M$. leprae and allow unhindered multiplication of bacilli in early stages of infection. The discrepancy in the skin and nerve histology was explained by the delayed recognition of $M$. leprae antigen which allows a build up of antigen within the nerves. ${ }^{12}$ Nilsen et al. ${ }^{1}$ classified patients with a bacterial index of more than $2+$ in their nerves as multibacillary. Negesse ${ }^{14}$ suggested that patients clinically and histologically diagnosed as tuberculoid, in whom nerve histology showed a BI of more than $2+$, might be classified as having dimorphic leprosy. We agree with Nilsen et al. ${ }^{1}$ and propose that such patients be classified as multibacillary on the basis of combined skin and neural histology, and treated with multibacillary drug regimens. This may reduce the incidence of relapse because the number of bacilli harboured in the nerves may be better tackled with MB type of MDT. Ridley \& Ridley ${ }^{12}$ concede that nerve histology might be of prognostic value in individual patients. There is need for further studies to compare the relapse rate of paucibacillary patients classified after study of concurrent skin and nerve histology and comparing them with therapy decided on the basis of skin histology findings alone. The skin histology will continue to be a standard tool in the confirmation of the diagnosis and classification of leprosy. The neural histology, whenever feasible, will give more information about the exact classification and immunological spectrum of the patient. Neural histology will be of use in classifying leprosy patients when skin histology is indeterminate or nonspecific.

\section{References}

1 Nilsen R, Mengistu G, Reddy BB. The role of nerve biopsies in the diagnosis and management of leprosy. Lepr Rev, 1989; 60: 28-32.

2 Antia NH, Pandya NU. Qualitative histology and quantitative bacteriology in various tissues of leprosy patients. Lepr Rev, 1976; 47: 175-83.

3 Srinivasan H, RaoKS, Iyer CAS. Discrepancy in the histopathological features of leprosy lesions in the skin and peripheral nerve. Lepr India, 1982; 54: 275-86.

${ }^{4}$ Haimanot RT, Mshana RN, McDougall AC, Andersen JG. Sural nerve biopsy in leprosy patients after varying period of treatment: Histopathological and bacteriological finding in light microscopy. Int J Lepr, 1984; 52: 163-70.

5 Ridley DS. Skin biopsy in Leprosy. Ciba-Geigy Ltd. Basle (Switzerland), 1977, 39-40.

${ }^{6}$ Katoch K, Ramanathan U, Natarajan M, Bagg AK, Bhatia AS, Saxena RK, Ramu. Relapse in paucibacillary patients treatment with three short regimens containing rifampicin. Int J Lepr, 1989; 57: 458.

7 Kaur S, Sharma VK, Basak P, Kaur I. Paucibacillary multidrug therapy in Leprosy. $7 \frac{1}{2}$ years experience. Ind J Lepr, 1992; 64: 1563-61.

8 Ridley DS, Jopling WH. Classification of leprosy according to immunity. A five group system. Int J Lepr, 1966; 34: 255-73.

9 Dharmendra. Studies of the lepromin test. A bacillus antigen standardised by weight. Lepr India, 1942; 14: 122-9.

10 Ridley DS. Skin biopsy in leprosy. Basel Documenta Geigy, 1985, 59.

11 Ridley DS. Pathogenesis of leprosy and related diseases. London: Wright, 1988; 168-71.

12 Ridley DS, Ridley MJ. Classification of nerves is modified by the delayed recognition of Mycobacterium leprae. Int J Lepr, 1986; 54: 596-606.

13 Mukher jee A, Misra RS. Comparative histology of skin and nerve granulomas in leprosy patients. Lepr Rev, 1988; 177-80.

14 Negesse Y. Leprous neuritis, classification of leprosy and multidrug therapy. Int J Lepr, 1988; 56: 329-30. 


\title{
Histologie simultanée de la peau et du nerf dans la lèpre et son rôle dans la classification de la lèpre
}

\author{
Surrinder Kaur, Vinod K. Sharma, Prasanta Basak, Inderjeet Kaur et \\ BISHAN D. RADOTRA
}

Résumé L'histologie simultanée de la peau et du nerf a été déterminée chez 60 patients atteints de lèpre (25 BT, $28 \mathrm{BL}$, et $7 \mathrm{LL})$. Le double but du projet était d'étudier l'histologie comparée et l'intérêt de l'histologie du nerf dans la classification de la maladie. Chez les patients BT, la classification clinique et histologique concordaient dans $11(44 \%)$ biopsies de la peau et $17(68 \%)$ biopsies du nerf. L'histologie simultanée de la peau et du nerf s'accordaient dans $14(56 \%)$ des patients BT, tandis que chez $6(24 \%)$ patients, seule l'histologie du nerf était utile pour la classification de la maladie, la biopsie de la peau n'étant pas spécifique. L'histologie du nerf a été classée en BL chez 3 (12\%) des patients BT, la biopsie de la peau n'était pas spécifique.

Dans le groupe BL, l'histologie de $23(82,4 \%)$ biopsies du nerf correspondait avec la classification clinique, par contre, la biopsie de la peau ne correspondait au tableau clinique que chez (68\%) patients. Chez les patients LL, l'histologie du nerf correspondait avec la classification clinique chez $5(71,4 \%)$, comparé à l'histologie de la peau chez $4(57 \%)$ patients seulement. Le GF était plus élevé dans les nerfs que dans la peau sur tout l'ensemble de la lèpre (BT, BL, LL), la différence était pourtant marginale dans la lèpre BL. L'index bactériologique moyen (IB) était plus élevé dans les nerfs $(4+)$ que dans l'histologie de la peau et les frottis de peau fendue $(3+)$ dans la lèpre BL. Il n'y avait pourtant pas de différence dans les IB des frottis de peau fendue, les biopsies de peau et de nerf dans la lèpre lépromateuse.

En conclusion, l'histologie du nerf convient mieux que l'histologie de la peau à la classification des patients lépreux $(p<0,01)$ et correspond mieux à la classification clinique, en particulier dans la maladie borderline tuberculoïde.

L'histologie du nerf a donné une meilleure idée de la charge bactérienne chez les patients BT et BL. Nous proposons que les patients à bactériologie négative, diagnostiqués par la clinique et l'histologie comme BT, mais avec une histologie du nerf correspondant mieux à BL soient considérés comme multibacillaires pour le choix du traitement.

\section{La histología concurrente de la piel y neural en la lepra y su papel en la classificación de la lepra}

\author{
Surrinder Kaur, Vinod K. Sharma, Prasanta Basak, Inderjeet Kaur y \\ BISHAN D. RADOTRA
}

Resumen Se evaluó la histología concurrente dela piel y neural en 60 pacientes con lepra (25 BT, 28 BL y $7 \mathrm{LL}$ ). El objetivo doble fue el estudio de la histología comparativa y la utilidad de la histología neural para la clasificación de la enfermedad. En los pacientes BT, la clasificación clínica e histológica correspondia con 11 $(44 \%)$ biopsias de la piel y con $17(68 \%)$ neural. La histología de la piel y neural concurrentes concordaba con 14 $(56 \%)$ de los paciente BT, pero en $6(24 \%)$ de los pacientes solamente la histología neural ayudaba en la clasificación de la enf ermedad ya que la histología de la piel no era específica. La histología neural fue clasificada de BL en $3(12 \%)$ de los pacientes BT, y la histología de la piel no era específica.

En el grupo GL, la histología de $23(82,4 \%)$ de las biopsias neurales correlacionaba con la clasificación clínica, comparada con la histología de la piela que correlacionaba con la evaluación clínica en $19(68 \%)$ de los pacientes. En los pacientes LL, la histología neural correlacionaba con la clasificación clínica en 5 casos $(71,4 \%)$, comparada con la histología de la piel de los 4 (57\%) pacientes. El GF fue más elevado en el caso neural que en el de la piel por toda la gama de la lepra (BT, BL, LL); sin embargo, la diferencia era muy pequeña en el caso de la lepra BL. El índice bacteriológico medio (BI) fue más en la histología neural $(4+)$ que en la histología de la piel y frótis de la piel cortada (SSS) $(3+)$ en la lepra BL. Sin embargo, no había diferencia entre el BI de los frótis de la piel cortada, y las biopsias de la piel y neural en la lepra lepromatosa.

Se concluye que la histoloía neural es más adecuada que la histología de la piel para la clasificación de los pacientes leprosos $(p<0,01)$ ye que correlaciona mejor con la clasificación clińica, especialmente en los casos tuberculoides dudosos.

La histología neural presenta una mejor idea de la carga bacteriana en los pacientes BT, BL. Se propone que los pacientes con un diagnóstico clinico e histológico BT, pero con una histología neural más consistente con BL, deberán ser considerados casos multibacilares para los propósitos terapéuticos. 